\title{
WestVirginiaUniversity
}

THE RESEARCH REPOSITORY @ WVU

Graduate Theses, Dissertations, and Problem Reports

2015

\section{You Can't Fight City Hall: Organization and Success in West Virginia}

Theodore Malone

Follow this and additional works at: https://researchrepository.wvu.edu/etd

\section{Recommended Citation}

Malone, Theodore, "You Can't Fight City Hall: Organization and Success in West Virginia" (2015). Graduate Theses, Dissertations, and Problem Reports. 6150.

https://researchrepository.wvu.edu/etd/6150

This Thesis is protected by copyright and/or related rights. It has been brought to you by the The Research Repository @ WVU with permission from the rights-holder(s). You are free to use this Thesis in any way that is permitted by the copyright and related rights legislation that applies to your use. For other uses you must obtain permission from the rights-holder(s) directly, unless additional rights are indicated by a Creative Commons license in the record and/ or on the work itself. This Thesis has been accepted for inclusion in WVU Graduate Theses, Dissertations, and Problem Reports collection by an authorized administrator of The Research Repository @ WVU. For more information, please contact researchrepository@mail.wvu.edu. 


\title{
You Can't Fight City Hall: Organization and Success in West Virginia
}

\author{
Theodore Malone \\ Thesis submitted \\ to the Eberly College of Arts and Sciences \\ at West Virginia University \\ in partial fulfillment of the requirements for the degree of \\ Master of Arts in \\ Sociology / Applied Research \\ Jason Manning, Ph.D., Chair \\ Jesse Wozniak, Ph.D. \\ James Nolan, Ph.D. \\ Department of Sociology \\ Morgantown, WV \\ 2015
}

Keywords: Organization, Legal Success, WV Supreme Court of Appeals, Court Success

Copyright 2015 Theodore Malone 


\title{
Abstract \\ You Can't Fight City Hall: Organization and Success in West Virginia
}

\author{
Theodore Malone
}

This research centers on the question of 'Who wins?' in criminal and civil cases heard by West Virginia's Supreme Court of Appeals. The study examines litigant characteristics and whether court winners are favored by virtue of their higher organizational levels, such as being business or government affiliates. The study is a partial small-scale replication of the prior research by Songer and Sheehan (1992) who determined that litigation resources that resulted from higher organizational levels predicated higher win rates in the United States Courts of Appeals. I utilized an array of cross-tabulations of success and litigant organization for a two-year sample of appeals $(N=434)$ and also compared winning with a measure of organizational superiority. Results garnered support for the theoretical proposition of Donald Black (1976), which states that law will react more harshly toward less organization, and more favorably toward more organization. Study findings suggest that higher organizational levels did realize greater success for litigants in West Virginia's appellate courts for the 2011-2012 term. The study also utilized a more detailed and complex approximation of litigant organizational levels that may be useful in further research exploring the relationship of organization with court success. 


\section{Table of Contents}

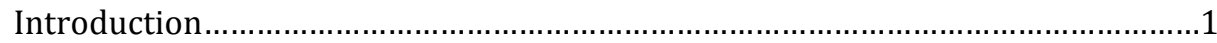

Theoretical Framework and Literature

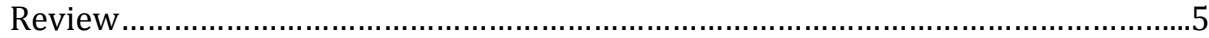

Donald Black and "Social

Geometry"

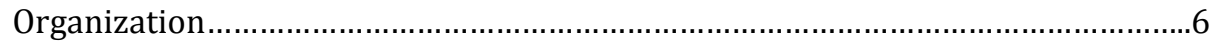

Previous

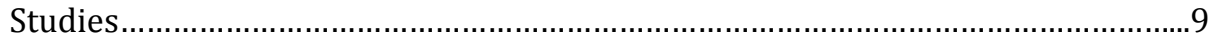

Data Source and Selected

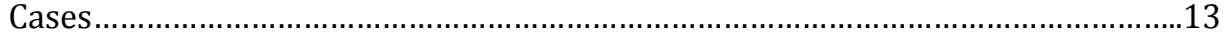

Case Dispositions and

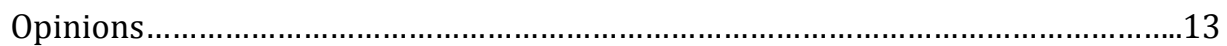

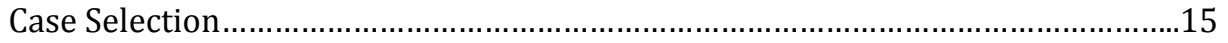

Variables and

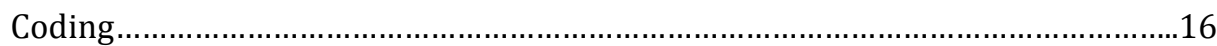

Analysis and Research

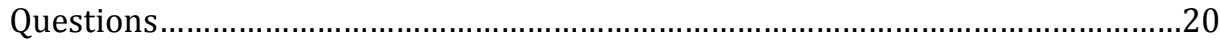

Net Advantage by Organizational

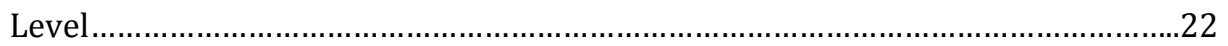

Advantage of Civil Over Criminal

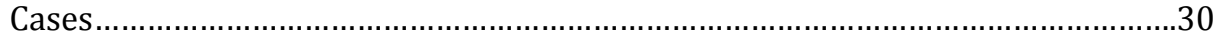

Limitations and Future

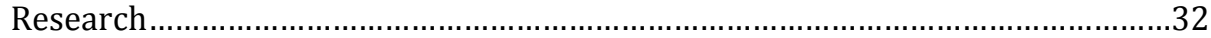

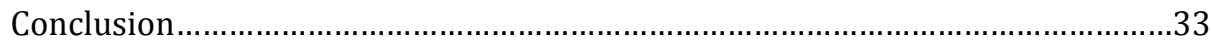

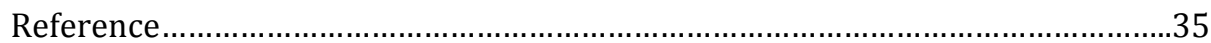




\section{Introduction}

Jurisprudence holds the precept that all are equal before the law, and in theory legal rules are applied universally, although scholars and sociologists long have thought this righteous ideal of legal equality to be a myth. Marx and Engels (1955 [1848]) suggest that all institutions in society systematically uphold the interests of the elite or ruling class. Reiman (1995) also purports that the rich perpetuate a status quo of inequality between the classes through law and the criminal justice system, and the public sees a distorted image of crime as being primarily an act of the poor. He points out that even the term "crime" is applied in such a way as to reflect this: "It (crime) is primarily reserved for the dangerous actions of the poor," pointing out that when deaths occur due to negligence of corporate interests, they are called accidents, not crimes (Reiman 1995:58-59). The common tendency is for law and order to be viewed in the framework of monetary stratification, but many (including this author) argue there is more to the matter.

In his classic work, The Power Elite, C.W. Mills (1956) presented a more precise assessment of the social order. Mills said that explanations that purport that society is ruled by economic or political forces alone are actually overly simplistic. He described a "power elite" who compose a political, economic, and military-industrial complex that exerts influence over society by nature of status and association. Mills said that a relatively small but powerful and organized "big three" network interchanges its members. Sometimes corporate officials will change jobs to political or military positions, and often the latter two groups will exchange staff with corporate firms. Mills suggested that in the United States this reign of the power elite began as early as the American Revolution and proceeded through the time of his writing, after the end of World War II (Mills 1956:6, 268-79). Were he alive today, one may speculate that Mills would attribute the current state of affairs with 
Indeed, cronyism and an "old boy" network are ideas not too distant from the context of Mills' and others' writings. There is an adage known in some circles that says that all goings-on in West Virginia are political except for politics, which is personal. With a small economy, smaller towns and only one law school and two large universities there are few or no degrees of social separation among the populace. For instance, Heather Bresch, daughter of former West Virginia governor now U.S. Senator Joe Manchin, retroactively 'earned' an executive MBA degree, having completed only 22 of the 48 required credits, ten years after the last date of her university attendance. After an inquiry, Bresch's degree was rescinded, and a university president, a provost, and two deans of the West Virginia University School of Business resigned over the matter (Urbina 2008). According to an investigative report, the dean and provost acted on insufficient information in granting the degree, and due to “...Ms. Bresch's high profile...she was, in fact, treated in an unusual and unique manner" relative to other MBA candidates at the time (WVU 2008:10,15).1

In a separate 2008 case before the West Virginia Supreme Court of Appeals, Chief Justice Elliott Maynard, acting in response to a court order, recused himself from a $\$ 50 \mathrm{M}$ securities fraud lawsuit being appealed by coal company Massey Energy. The judge initially had voted in a 3-2 decision favoring Massey, whose CEO, Don Blankenship, is Maynard's long-time friend. Incidentally, Blankenship currently faces a 30-year sentence for combined federal fraud indictments for this incident and also for negligence and fraud charges surrounding the 2010 Big Branch Mine disaster that killed 29 in West Virginia. Despite millions of dollars in fines, Massey Energy survived relatively unscathed, recently purchased for some $\$ 7.1$ billion by competitor Alpha Natural Resources. Some might argue that Massey's role was in "taking the fall" for the coal company; nonetheless he was able to obtain a three-month reprieve to the start of his criminal proceedings.

${ }^{1}$ This statement was made in response to the investigative panel's question on whether Ms. Bresch had been treated the same as other MBA candidates considered at the times of her enrollment and her retrospective degree awardship. 
Though the "official" reason for filing the reprieve motion was a high volume of case paperwork, the multi-millionaire former CEO of Massey earned this initial pause in a case yet to ultimately be decided. (Liptak 2008; Pearson and Milford 2015).

While corporate or political affiliations may earn favor before the law, fame and fortune may also help. In the well-known O.J. Simpson criminal case, the national football icon and sports commentator was acquitted of all charges, despite DNA evidence linking him to the murders of his wife and acquaintance. Even a civil suit targeting Simpson failed to take hold for several years before its merits were finally heard. Simpson hired 9 legal advisors for his murder trial, one of whom was successful Harvard professor and Constitutional lawyer, Alan Derschowitz, who in his legal career successfully exonerated some of the wealthiest and highest profile criminal defendants. The average defendant cannot afford to pay for such expensive private counsel or legal advisors.

In 2011 in another criminal case, country music superstar Willie Nelson's near $1 \frac{12}{2}$ pound drug possession resulted in a mere $\$ 500$ fine for a (reduced) “paraphernalia” charge, and after 30 days even this charge dropped from Nelson's permanent record due to his "staying out of trouble" for a month. Nelson had several prior drug possession arrests for which he served no jail time, including a 2006 charge for possession of 1.5 pounds of marijuana and several ounces of hallucinogenic drugs (Duke 2011).

While in some cases celebrities, the wealthy, and the organizationally affiliated may get legal favor when they need it, other cases involve extreme civil liberties violations committed by government entities or officers who may be devoid of serious consequences. For instance, in 2014 in the mostly African-American town of Ferguson, Missouri, police took the life of unarmed 18-yearold black resident, Michael Brown, who was shot six times and killed after resisting arrest. Officer Wilson, the shooter, later avoided indictment for misconduct. In the following months, amidst nationwide riots, events culminated in a federal investigation, the resignation of police personnel, 
and the subsequent protesting and firearm assaults against police. Perhaps most important to the

Ferguson incident is the US Justice Department investigation that uncovered many civil rights and fining violations. According to that report, Ferguson police issued 50\% more municipal citationssome 90,000--during the 2014 fiscal year, while serious crimes such as theft and DUI remained constant. Officer evaluations depended on the issuance of tickets in what equates to a quota system, and findings suggested that police practices operated to generate revenue and reflected both racial bias and stereotyping (US Department of Justice 2015:6-10;15). In nearby Washington, D.C. unconstitutional seizures of funds and assets are so commonplace that police announce plans for the use of anticipated seizures prior to their acquisition. All over the United States (including Ferguson, Missouri) police are using seized funds to purchase costly equipment and resources in a process known as "Equitable Sharing." (Washington Post 2014).

Whether or not government officials serve the interests of a capitalist or power elite, organizational position does hold some legal advantage. One might consider for illustration a case close to home. In 2013, in Martinsburg, West Virginia, police shot African-American Wayne Jones 23 times...killing him. Allegedly causing an officer what amounted to a flesh wound, Jones, suffering from schizophrenia, had characteristically avoided police and ignored questioning over his walking the street. Authorities left Jones' lifeless body uncovered for four hours, while the officer was treated and released from the scene immediately. None of the officers, who allegedly altered the video of the shooting, were indicted for misconduct. The Berkeley County Circuit Court dismissed a $\$ 200$ M lawsuit, and Jones' estate declined a subsequent $\$ 200,000$ settlement offer (Martinsburg Journal 2014). Perhaps this dismissal is another case whereby "the powers that be" exercised legal advantage.

If favor is conveyed to benefit the wealthy or affiliated and not to the poor or those lacking status, it is perhaps most often granted to members of the proverbial "City Hall." Whether they are business or government organizations, the "haves" of the world maintain the status quo, winning
Jason Phillip Manning 5/1/2015 12:12 PM

Comment [1]: Cut

Jason Phillip Manning 5/1/2015 12:12 PM

Comment [2]: You should probably mention that the town is mostly black.

Jason Phillip Manning 5/1/2015 12:12 PM

Comment [3]: Result of

Theo Malone 4/12/2015 3:49 PM

Formatted: Normal, Line spacing: double 
legal battles through their influence. Additionally, consequence often does not come to police and legal players who automatically have a certain cache--a governmental employer, a heavy purse, or

some other advantage. Simply having the ability to hire one's own attorney is advantageous,

especially with over-burdened court-funded attorneys, who serve as the constitutional guarantor of

legal "fairness" through provision of legal representation for all. Clout may be just what wins in the world of legal pugilism, and being able to hire expensive legal counsel is a commodity not afforded

by all. However, I assume in this article that organizational status is the key factor to legal favor. My work investigates how the law treats individuals and organizations differently.

\section{Theoretical Framework and Literature Review}

\section{Donald Black and the Law}

The framework of this article originates in Donald Black's theory of law. In his book, The Behavior of Law (1976), he describes law as governmental social control. As differences in case processing are attributed to variations in law, these variations coincide with an inconsistent treatment of deviants according to social factors. Black says that law is a quantitative variable measurable by the amount of action of the law. For instance, a call to the police is one level of legal action; a formally filed charge is another, and a court action is yet another. Additionally, each of the aforementioned legal scenarios represents a different degree of action, or quantity of law. A phone call is less law than an arrest, and an arrest is less law than a court sentence, and so forth. Relative to law and its varying quantitative degrees, Black says that other factors may coincide with the various actions and the subsequent "behavior" of law. Additionally, this behavior depends on its context, 


\section{"Social Geometry" and Covariates of Law}

Black defines social geometry as “... location and direction in social space.” (Black 1976;184).

Accordingly, he says that law varies by the social geometry of individual legal cases. For example, in two technically identical third degree murder cases, litigant characteristics and case details like the differing statuses (cultural, socioeconomic or otherwise) of victim and offender often drive different outcomes. Legal cases involving socially upward crimes (those committed by a lower status perpetrator against a higher status victim) will attract a greater quantity of law and likewise the opposite. That is to say, the category of crimes occurring from a higher status perpetrator against a lower status victim will attract less law and typically less severe consequences (Black 1976:19, 85-86). For instance, if a criminal has a lower educational level than a victim, the legal punishment may be greater than in cases where the criminal is the more educated of the two, When a criminal is more educated the law will yield a more favorable outcome, perhaps a reduced sentence or even an acquittal. As such, and in keeping with the above example, in a third degree murder case wherein a law professor is responsible for the death of a student (who we will assume is the less-educated) the professor will more likely than not receive some legal favor or less harsh penalty, as opposed to a situation when the same crime occurs from the opposite direction (in other words when a student is found responsible for the death of the more educated, higher status professor):

\section{Organization}

\section{A fundamentally important aspect of the legal case is the organization of its jitigants. According}

to Black, organization is a quantitative variable that can predict legal favor. As such, he observed and also devised measures of organization in his studies of the law $\|$ With regard to litigant status and of particular theoretical importance to the current study, Blackdefines organization as a quantitative variable, a “...capacity for collective action...found in any group” (Black 1976:85). He
Jason Phillip Manning 5/1/2015 12:12 PM

Comment [6]: Cite specific page numbers for quotations.

Theo Malone 4/14/2015 1:08 PM

Deleted: 2010

Jason Phillip Manning 5/1/2015 12:12 PM

Comment [7]: cut

Theo Malone 4/12/2015 10:49 AM

Deleted: : this is what Black refers to as

'location and direction')

Jason Phillip Manning 5/1/2015 12:12 PM

Comment [8]: You should cite specific page

numbers from books.

Theo Malone 4/12/2015 10:51 AM

Deleted: ; Black 1989

Theo Malone 4/15/2015 11:33 AM

Deleted: ; this cultural difference is the

aforementioned magnitude

Theo Malone 4/15/2015 11:34 AM

Deleted: or

Theo Malone 4/14/2015 1:03 PM

Deleted: Other litigant social

characteristics or factors predictive of legal

inequality are socioeconomic status and

relational distance between litigants or

between perpetrator and victim. For

instance, Black would suggest that if a

criminal is poor and his or her victim

wealthy, the legal consequence is greater

than if the relationship is reversed.

Similarly, if the relational distance is greater

between criminal and victim (the two are

less affiliated than relatives or lovers, for

instance) the legal consequence is greater

than would be so in an opposite

circumstance (Black 1976; Black 2010). .

Theo Malone 4/12/2015 10:41 AM

Deleted: To

Jason Phillip Manning 5/1/2015 12:12 PM

Comment [9]: cut

Theo Malone 4/12/2015 10:38 AM

Deleted: (the primary independent variable of the current study)

Jason Phillip Manning 5/1/2015 12:12 PM

Comment [10]: This is irrelevant since it's not

the proposition you are testing.

Theo Malone 4/12/2015 10:40 AM

Deleted: states "Law varies directly with organization;"

Theo Malone 4/12/2015 10:40 AM

Deleted: he clearly 
instructs the reader of the ways in which this collective potential can be measured, saying that organization will “...include presence and number of administrative officers....and decision-making, and the quantity of collective action itself" (Black 1976:85-86). By virtue of this quantitative aspect of his definition of organization, Black predicts that the law will generally favor those present in numbers and those of superior organizational capacity. Thus an individual is less organized than two or more individuals, who are in turn less organized than a small business, which is less organized than the state government, and so forth. $\downarrow$

While much can be said about Black's theory of law and different covariates of legal action, this study focuses primarily to test Black's proposition, "Law is greater in a direction toward less organization than toward more organization" (1976:92). This proposition suggests that the higher is one's organizational level, the better will be his or her probability of legal success and the less likely the potential for loss. This means that in court, organizations (businesses, governments, etc.) will always have a higher likelihood for success than individuals. Stated another way, criminal appeals by individuals will more likely favor the (implied) governmental opponent, and civil cases likewise are be expected to favor organizations over individuals. For example, there are often higher penalties for criminal offenses committed against US Postal service (theft, vandalism, and the like) than for equivalent crimes directed against lesser government affiliates such as state boards of education and schools; similarly, one faces higher penalties for offenses against police and other governmental representatives than for equivalent crimes against less organized affiliates or individuals (Black 1976:85-87).w.

Why might organizations have such an advantage? In his groundbreaking essay, "Why the Haves Come Out Ahead: Speculations on the Limits of Legal Change," Marc Galanter (1974) adds to the theoretical framework the current study explores. Galanter claims that organizations such as business and governmental litigants are more often what he coins "repeat players" in the court 
system, while individuals are usually "one-shotters."

level court experience, such as the plaintiff (or defendant) in personal injuries cases, the divorcee,

the drunk driver, and so on. Conversely a "repeat player" is the more advantaged litigant in the

sense that he or she somehow has better chances for success, either by being more accustomed to

transacting business in court or in having some level of status granting other legal advantages. For example, Galanter points out that business party repeat players enjoy advantages by virtue of benefits accessible via their existing employees:

"RPs develop expertise and have ready access to specialists...RPs may enjoy access to competent paraprofessional help that is unavailable to OSs (one-shotters)...Thus the insurance company can by employing adjusters, obtain competent and experienced help in routine negotiations without resorting to expensive professionally-qualified personnel" (1974:98).

Repeat players are generally those of higher status and are thus dominant parties in court. They have greater stability and success, and by virtue of ongoing legal involvement or of recognized status, they navigate the legal realm with few or no setbacks and a net gain. In the sense that repeat players have more experience, they can "play by the rules" that matter most to winning; this means that they can find the legal loopholes and play their cases from such angles in order to succeed. The repeat player is able to utilize legal rules that make a difference in the most practical sense: they “...are more able to discern which rules are likely to 'penetrate' and which are more likely to remain mere symbolic commitments" (Galanter 1974:103). Galanter is referring to this privileged access that repeat players have to legal rules that allow their success, by nature of their experience and resources, in a system that is only formally designed to equally favor both parties.

Galanter's argument does not suggest there is a conspiratorial effort by those in power to dominate those who are not; alternately he points out that the advantages conveyed to those of 
status are not granted automatically: The advantages of repeat players are normative to the actual legal process; there is no favor conveyed by secret handshakes or judge chamber meetings, and status does not automatically guarantee success. The repeat player enjoys advantages resulting from both assets and knowledge that go with his or her high status as well as from experience and familiarity with the court system. Several empirical studies tested the theoretical propositions of Black and sought evidence for Galanter's discussion regarding status-based legal advantage.

\section{Previous Studies}

In his research-based article, “The Public Ordering of Private Relations,” Craig Wanner (1975) suggests that the law is a tool manipulated by the advantaged, and it may serve to promote or sustain institutional discrimination. His study's results seem to affirm the idea that law favors organization via less-than-impartial actions (Wanner 1975).

Wanner studied city court civil trials from Baltimore, Milwaukee, and Cleveland from 1971 to 1972 and sampled cases from court archives for the years 1965 to $1970(N=7800)$. Wanner coded data by case type, outcome, date, litigant, attorney, number of proceedings per case, monetary amounts disputed and damages awarded. He examined case styles by frequency, organizational class wins, and by city. He later performed factor analyses of successes and examined cases according to litigant class combinations: individual versus business and individual versus government. The results characterized the have-nots primarily as individuals and the haves as businesses and corporations, as well as government entities. Business and government plaintiffs and defendants had the highest win rates; these high status members were also better prepared for funding litigations and for handling losses,_and were better accommodated and facilitated by the court when filing motions. (Wanner 1975). several variables may be tantamount to the actual outcome or presumed relationship between dependent and independent variables. Other mor 
Songer and Sheehan (1992) also question winning as regards litigant organizational status in their own study on the haves and have-nots, which yielded more support for Black's proposition that higher organization is favored through legal advantage. The study examines a large caseload $(N=4281)$ from the Fourth, Seventh, and Eleventh circuits of the US Supreme Courts of Appeals combined (for 1988). The authors' dichotomy of inequality named "upperdogs," and "underdogs" as the haves and the have-nots, respectively, creating a special set of subcategories of organizational levels to consider success to both the poor and to the privileged. They also generally examined four classes of organization in terms of success. These were individuals, businesses, local and state governments, and federal government. All other litigants were designated as a class named 'other' and included voluntary memberships, nonprofits, schools, and political organizations; these were not included in the authors' analysis of the four level litigant classification. Songer and Sheehan found that upperdogs (the haves) nearly always came out ahead and were so acclimated to the court system that they were often even able to engage in forum shopping for the potentially most profitable legal battles, even deciding which civil cases were worthy of a fight and which were better to seek a settlement. Their study relates a winning advantage for the privileged (typically those of a higher status than individuals).

Songer and Sheehan also examined win rates for different scenarios in which litigants of different levels of organization were matched as court opponents. In this way, the authors were able to generalize about the different types of matchups, as well as determining each litigant type's win rate as either appellant or respondent. Further, each litigant class's rate of success was reported in terms of a relative advantage measure computed by subtracting from an appellant's success rate that of its opponents when that appellant class appeared as respondent; this measure reflected individual organizational class advantages independent of the effect caused by the tendency of the appeals courts to affirm (in the current study upwards of 90\%). According to the research of Songer and Sheehan, The US Supreme Court of Appeals data also showed a net advantage for federal 
government of $45.1 \%$, followed by local and state governments at $29.0 \%$, with businesses at only $1.6 \%$ and individuals at nearly $18 \%$, clearly indicating an organizational advantage (Songer and Sheehan 1992:242-243).

Though I do not incorporate their method in the current study, Songer, Kuersten, and Kaheny (2000) expanded the research question of who wins in court by considering whether amici curiae (literally "friends of the court") involvement had any effect on state supreme courts decisions. They focused specifically on cases in which the advantaged did not always win. The researchers studied data from three separate state appellate courts for the years 1983-1990: North Carolina, South Carolina, and Georgia. Utilizing 20 randomly-selected civil and criminal cases sourced from Westlaw with a stratified random sample of cases taken from the Southeastern Reporter, they examined all cases with regard to winning when amicus persons filed briefs on behalf litigants, both when filing on behalf of appellants and also respondents. The researchers found that amicus involvement was helpful both to "upper dogs" and "underdogs," but ultimately it was most beneficial to "underdogs." This occurred to such an extent that in some cases it "leveled the playing field" between the two groups (Songer, Kuersten, and Kaheny 2000).

In consideration of the research studies just mentioned, the current study aims to further examine how organization influences case outcome in West Virginia's Supreme Court of Appeals.

Few $w_{\nabla}$ studies have examined the relationship with a recent case sample, and to date none have focused specifically on West Virginia. As such, the current study aims to address a gap in the literature by selecting from a new data set to test the theoretical proposition that law reacts least favorably toward those having lower organizational status and conversely predicates a higher relative success for those of higher levels of organization.

The current study presents another important question in the framework of West Virginia appellate court: “Do civil cases differ from criminal ones as regards equitable treatment?" 
According to Black's theoretical argument one would expect that since higher levels of organization are associated with higher court success and legal favor, the criminal case will have, the greatest degree of difference between litigants: government (the highest order of organization) against individuals (the least organized). Accordingly, cases of this style will somewhat consistently reflect a harsher consequence of law toward individuals. Conversely, civil cases often involve varying degrees of organizational difference, and as such will reflect more variation in overall appellant success, certainly better than for criminal cases in which the opposing government party can usually expect to win. For instance, a divorced couple may litigate in a civil matter over disputed assets in a partnered business, or a disgruntled employee may sue over wrongful dismissal and wage garnishment. Perhaps a civil class of individuals will litigate against an organization or government agency, or a business may file suit against a government regulatory firm, or some similar scenario. As such, in the civil case, where the degree of organizational difference between parties varies, it is reasonable to expect that appellant parties will generally enjoy more equitable treatment by the law than in cases of government versus jndividuals (criminal matters).

Though the success differential for civil style cases versus criminal ones may not seem immediately important, further examination may urge some consideration for legal reform. In comparing the current compulsory criminal justice system with the currently optional nature of a civil one, Black (1976) suggests there is much potential for change, utilizing as example the Japanese legal system as one that is perhaps better than our current one and not so inundated with inequity. Galanter (1974) also gives serious consideration to legal restructurings in his writings. The goal of such reforms is to facilitate greater equality among litigants, and this notion again reminds the reader that such idealized egalitarianism is merely a supposition upon which the legal system is already based. The true state of affairs as revealed by data here and elsewhere may be an impetus for judicial overhaul. Rousseau referred to the need for a periodic legislative equalization, which in the present day could arguably justify all-out reforms. "It is precisely because the force of
Theo Malone 4/15/2015 11:53 AM

Deleted: and

Theo Malone 4/15/2015 11:53 AM

Deleted: is the one

Theo Malone 4/15/2015 11:53 AM

Deleted: th

Theo Malone 4/15/2015 11:54 AM

Deleted: any combination Theo Malone 4/15/2015 11:54 AM

Deleted: style

Theo Malone 4/15/2015 11:54 AM

Deleted: ly

Theo Malone 4/15/2015 11:54 AM

Deleted: ed

Theo Malone 4/15/2015 11:55 AM

Deleted:

Theo Malone 4/15/2015 11:55 AM

Deleted: 
circumstances tends continually to destroy equality that the force of legislation should always tend to its maintenance" (Rousseau 2010[1910]:39-40).

\section{Data Source and Selected Cases}

\section{The West Virginia Supreme Court}

The West Virginia Supreme Court of Appeals is the state's highest court. It hears criminal, civil, and administrative cases appealed from county circuit courts, just as county courts are also responsible for hearing cases successfully appealed from town and municipal courts. Cases affirmed by the West Virginia Supreme Court of Appeals are in turn the legal jurisdiction of the US Supreme Courts of Appeals, though cases in such scenarios are outside the scope of this study. As is the case with the data utilized here, the majority of state-level appeals are decided in finality by state appellate courts, never reaching the federal level of appeals. As such the judicial body whose cases I examine in the current study is the terminal point of the majority of successfully appealed cases in the state. I remind the reader here that the majority of appeals cases are affirmed (the request in the appeal is denied); therefore most appeals go no further than the court hearing the appeal. The Mountain State's highest court also hears cases raised by governmental organizations for administrative decisions, such as those of the West Virginia Department of Education, the Department of Motor Vehicles (DMV), as well as those of both the West Virginia Bar Association and the Lawyer Judiciary Board. Additionally, the court oversees worker's compensation issues and those of other administrative organizations such as the Department of Environmental Protection.

\section{Case Dispositions and Opinions}

Case dispositions for the West Virginia Supreme Court of Appeals are organized as opinions publicly available in a database of accessible via the website www.courtswv.gov/supreme- 
court/opinions.html. Opinions in the database document court decisions regarding civil, criminal and administrative matters; these include detailed case synopses. The database archives opinions issued from 1991 to the present day for cases originating in West Virginia's fifty-five counties. Case styles include civil actions, criminal proceedings, and administrative matters. Civil actions include torts, real property, and contract law matters. Criminal actions involve various crime types, including the criminal categories utilized by the FBI's Uniform Crime Reporting (UCR) index. Issues not in the scope of sampled cases include Lawyer and Judiciary Board matters and those of the WV Bar Association, as well as certified questions issued by federal or non-WV courts, and administrative and worker's compensation matters. One can search the database by case number, names of litigants, or by biannual terms in chronological order of occurrence.

Case dispositions are classified in several ways, including signed opinions (SO), also called "slip opinions"; memorandum decisions (MD); per curiam opinions (PC) (also published separately for reference as legal precedents listed in the West Virginia court reports); concurring or dissenting opinions (SEP) are also in the archive as separate files submitted by single justices of the five-judge appellate panels. The latter have no bearing on the sampled cases upon which they are based, and, as such I do not include these cases in the study, due to their being for being 'split' decisions (not 'win' or 'lose, outcomes).

Case opinions contain a detailed array of additional information including dates of appeal and counties from where appeals originate; names of appellants (bringers of appeals) and respondents (their opponents); reason for appeal; original case details, lower trial court decision, and written arguments and syllabus points (in signed opinions) of justices. Outcomes are listed as "affirmed," "reversed and remanded," "reversed," "remanded," "vacated," "reversed and vacated," and "dismissed." Reversed" means prior decisions are overturned by the West Virginia Supreme Court of Appeals. "Remanded" means a prior decision is nullified and returned to the original court venue 
(often with instructions) for decision. "Dismissed" indicates that the current appeal is nullified and declared as unworthy of further discussion. "Vacated" is the technical equivalent of "dismissed." Affirmation is the most common case disposition ( $85.7 \%$ for this study), and as already stated, courts historically maintain greater than the idealized $50 \%$ affirmation rate that might exist in a perfectly egalitarian legal system (Songer and Sheehan 1992:240), perhaps reflecting a somewhat automatic deference to already decided court rulings. "

\section{Case Selection}

In this study I selected for analysis only affirmed or reversed_or dismissed or vacated) criminal and civil appeals cases from the 2011-2012 term $(N=434)$. I did not include in the analysis any partial decisions. Prior studies using appellate courts data often included all listed appeals case styles, as well as mixed outcome cases ('affirmed in part, reversed in part'). In the current study I limited the scope to the two general categories of appeals: criminal and civil actions. I chose to control for case type selection in this manner for several reasons, with primary consideration given to comparing the size of organizational advantage across case type; in other words, allowing for administrative cases and family law matters creates a large sample caseload having identical organizational levels (individual v. government), Though controlling for case style could be accomplished through statistical controls, controlling at the level of the sample was thought most appropriate due to the limited sample size. According to Black's theory, comparing criminal versus civil cases predicts a lower rate of success for the former, which are typically appealed by individuals against state, municipal, or county accusers. $I$ desired a better view of organizational variation than criminal cases alone, and thus I also included civil cases. 


\section{Variables and Coding}

The data used for analysis here come from cases of the years 2011 through 2012. The dependent variable 'winning' is defined according to the case dispositions referred to above in the same methodology as used by Songer and Sheehan (1992); in other words, a success is coded as a '1,' while a failure is coded ' 0. ' A case that is "affirmed" is considered a loss for purposes of analysis; all others are wins; the latter can include dismissals or vacated decisions, reversals, remands, or some combination thereof. It should be noted here that independent of this coding scheme, an actual loss is only considered as such from the perspective of the litigant: A 'loss' to an appellant (an affirmed case) is a win to a respondent and vice versa.

For appellants and respondents I further utilize the litigant organizational classes used by Songer and Sheehan (1992) in addition to a more complicated expanded-type organizational classification strategy. Songer and Sheehan defined organizational classes as 'individuals,' 'businesses,' 'state and local government,' federal (national) government,' and 'other' (other organizations). In this study, I use these same categories, except for 'national government' (as WV appeals data only includes state or local government levels of organization) and 'other.' In addition, I use the following organizational designations: 'individuals,' 'multiple individuals,' 'classes (of individuals or parties)' as in class action suits, 'small businesses' and 'large businesses,' 'local and state government,' and 'voluntary organizations' for membership organizations or trade unions. As mentioned previously, other levels of organization do exist, such as national governments and other authorities to which governments are supposed to be accountable-for example the United Nations' (UN) International Court of Justice (ICJ). Higher organizational levels are subject matter for future studies, and for the purposes of this research state appeals courts data restrict organizational levels by only dealing with litigants who are at the highest category--state government. Higher-level litigants (national government status or higher) are only participants in tribunals such as the United States Courts of Appeals or the United States Supreme Courts. The two organizational classification strategies I 
utilize in the current study both line up with Black's theory, except for voluntary organizations and classes in the expanded-type, which should be considered with caution due to limitations unique to this study (e.g. too few such observations available for analysis). Differences in the two organizational scales have some merit for future exploration, particularly for reasons of possible benefits of using the more complicated expanded-type of classification, which I will discuss later.

\section{Measures of Litigant Success}

Though litigant classes were identical for appellant and respondent, I thought it best to present an expanded classification type in this study ${ }_{n}$ along with the Songer-style one. This more complicated scheme may prove to be important in considering data and how they support or do not support theoretical relationships. As did other researchers before me, I devised an index of net advantage among different parties, also very important with respect to litigant winning. This is a calculation of the difference between a litigant class's success as appellant and its opponents' success when the former is appearing as a respondent. For example, to calculate the index of net advantage for individuals I subtract the total success rate of all opponents when individuals appear as respondents from the overall success enjoyed by individuals when appearing as appellants; the difference is the net advantage for individuals. The importance of this variable is that it indicates success for an organizational class superior to its raw success rate would do. This is due to the fact that the measure is not distorted by the relative frequency that a class appears a respondent or appellant when considering general success rates (affirmation rates) of appeals cases, which transcend litigant characteristics. In other words, if an organizational class appears in court more (or less) as a respondent than as an appellant, by its raw success rate it will then appear more or less successful due to the general propensity for courts to affirm (Songer and Sheehan 1992:242). With the current study's analysis reflecting an $85.7 \%$ affirmation rate (chi-squared probabilities at
Deleted: approach

Deleted: appears 
the 0.001 level or better), this measure is certainly very useful, perhaps even more so with government appearing as the respondent in $59 \%$ of cases (257 out of the total 434 cases).

Another variable of considerable significance to this study is the index of relative strength between litigants. It relates directly to the question, "To what degree does difference in organizational strength predict court winning? Index of relative strength is important because it highlights the degree of difference of organizational strength versus the favor of the legal system as indicated by rate of court success. As discussed below, the measure shows whether success rates increase consistently with incremental increases in organizational strength according to the relative differences in strength for appellants versus respondents. According to Songer and Sheehan, a linear presentation of this organizational difference in relative strength with success supports the theoretical proposition that higher organization (and a higher positive difference in organization between court opponents) predicts greater favor of the law (1992:246-247). The relative strength index is found by subtracting from an appellant's numeric level of organization the opposing respondent's corresponding organizational level (for each coded case); the index of relative strength corresponds to a specific court success rate. Before one can calculate the value of this variable, all litigants first are assigned a numerical organizational level: 1,2 , or 3 in the Songertype scheme and between 1 and 7 according to the expanded-type organizational classification; this range of differences and corresponding success rates are displayed in Tables $4 \mathrm{a}$ and $4 \mathrm{~b}$.

Following the methods of Songer and Sheehan, I coded individual litigants involved by virtue of their official roles in organizations at the levels of those associated organizations, but only when the individuals' court involvement was by virtue of that organizational association (Songer and Sheehan 1992:237-238). For example, if a litigant is a police officer whose organizational title is 'Corporal First Class' and he or she is named as an original respondent in a civil suit against the West Virginia State Police, the variable for respondent is coded a '7' (local-state government). 
Similarly, if an appellant or respondent party includes more than one individual, then the variable for that litigant is coded according to the status of the member having the highest level of organizational affiliation. In the previous example for the state police officer, the litigant is coded as a '7' (state government) even if other individuals or businesses are named as respondents. In another example, perhaps a class action suit appealed by respondents John and Jane Smith, listing as co-litigants Jim and Sally McCoy and the Woods Resort, Inc., the corresponding appellant organizational status is coded according to the highest-status organizational member, in this case '4' (small business), since the resort is included in the list and has the highest level of organization.

\section{A Note on Appellate Courts, Case Names, and Appellants and Respondents}

The reader should also be aware that due to the often cyclic nature of appeals and mechanics of appellate courts, when a decided lower court case is heard as an appeal in appellate court, the 'loser', in the previous case automatically takes the identity of the appellant in the appeals court, regardless of whether previously the plaintiff or defendant. This party is raising the appeal, and thus he or she becomes the appellant in the higher court of appeals, and accordingly, the opponent

is at this point in time the respondent. For example, a lower court decision may favor Party A, and so

Party B appeals; another ruling follows and favors Party B, and then Party A appeals again, and so on. Similarly, in cases involving multiple entities as litigants, a single member of the group of litigants (or some subset thereof) may initiate an appeal, or perhaps a member of a class may initiate a cross-appeal or some other such development. Worthy of note also is that in the West Virginia Supreme Court of Appeals, cases may still be titled according to the format used in the original case first appearing before the appeals courts (or before the lower courts). In such a scenario, the title format may be Appellant $v$. Respondent when one would perhaps expect the appeal to read correctly according to the format of the current appellant and respondent. For instance, for an appeal of a circuit court decision by appellant John Smith against 'State of West 
Virginia,' the original case may have been titled, 'State of West Virginia v. John Smith.' The case to be heard by the West Virginia Supreme Court of Appeals may still remain named in this manner: State of West Virginia v. John Smith--when it accurately should read, 'John Smith v. State of West Virginia.' In the coding scheme of the data for this study, the case titles sourced from the original appellate courts database have likewise not been altered, and thus it can at first be difficult to determine the actual statuses of appellants and respondents by reading the case titles.

\section{Research Hypotheses}

H1: Court success rates will be greater for higher organizational levels than for lower ones.

H2: An organizational advantage index will indicate that the higher the indexed difference of relative degrees of organization, the higher will be the win rate for the dominant party.

H3: Generally, civil appeals will have a higher success rate than will criminal appeals.

\section{Analysis}

This research examines litigant success rate according to seven organizational categories and includes a condensed comparison according to organizational levels utilized in the Songer and Sheehan (1992), study, excluding their fourth measure, federal government, The latters' organizational levels include individual, business, state or local government (and federal government). In keeping with the Songer and Sheehan methodology, the current study performs a 
set of similar comparisons via cross-tabulation, also allowing for comparisons by the expanded

organizational category scheme above that of Songer and Sheehan, as mentioned above. ${ }^{3}$

\section{Litigant Success}

Since the dependent variable in the current study is the win rate for WV Supreme Court of

Appeals litigants by their respective organizational levels, the starting point for analysis was to examine these rates by litigant classification. This includes both the expanded-type (including the 7 stages devised for the current research) and the modified Songer-type. ${ }^{4}$ As can be seen in Tables $1 \mathrm{a}$ and $1 \mathrm{~b}$, government enjoyed an overall $60 \%$ appellant success rate very $_{w}$ close to the $58.2 \%$ reported by Songer and Sheehan. Next came business with $34.9 \%$ overall success (combining the small business and large business categories that had win rates of $25 \%$ and $53.8 \%$, respectively). Multiple individuals enjoyed about double (18\%) the appellant successes of single individuals, while classes won none $(0 \%)$ of their appeals and voluntary organizations won one of two times $(N=2)$ it appeared as a respondent. All organizational party winning results reported here were generated from data tables for which chi-squared tests were quite significant (Chi-square $=44.92$, $d f=20, p<0.01)$

\footnotetext{
${ }^{3}$ The categories of organization devised here, voluntary organization and classes in some cases produced so few observable scenarios that the decision was made that these should be considered only with caution. For purposes of clarity I left them intact and organized in the tables that follow.

${ }^{4}$ The implication here is that in these different organizational classifications the 'government' category remained unchanged due to coding including only one litigant level designated 'government.' The expanded organizational classification allowed for a differentiation in successes of in-state, small business and interstate, large business, as well as for multiple individuals and classes, while the latter two categories' win rates are reported along with very small numbers of observations ( $N=50$ and $N=3$, respectively).
} 
Table 1a. Appellant Success against Respondents ('Songer-type' Organization)

\begin{tabular}{|c|c|c|c|c|}
\hline Respondent $\rightarrow$ & $\begin{array}{c}\text { Individual } \\
(N)\end{array}$ & $\begin{array}{c}\text { Business } \\
(N)\end{array}$ & $\begin{array}{c}\text { Government } \\
(N)\end{array}$ & $\begin{array}{c}\text { Total \% } \\
(N)\end{array}$ \\
\hline Individual & $9.3 \%$ & $20.8 \%$ & $8 \%$ & $\mathbf{1 0 . 8}$ \\
& $(5)$ & $(16)$ & $(20)$ & $(381)$ \\
\hline Business & $35 \%$ & $35.3 \%$ & $33.3 \%$ & $\mathbf{3 4 . 9}$ \\
& $(7)$ & $(6)$ & $(2)$ & $(\mathbf{4 3 )}$ \\
\hline Government & $50 \%$ & - & $100 \%$ & $\mathbf{6 0}$ \\
& $(5)$ & & $1 / 1$ & $(\mathbf{1 0 )}$ \\
\hline
\end{tabular}

For the tables used to generate the data in the tables above $N=434$, Chi-square $=19.16, d f=4, p<0.01$.

Table 1b. Appellant Success against Different Respondents ('Expanded-type' Organization)

\begin{tabular}{|c|c|c|c|c|c|c|}
\hline Respondent $\rightarrow$ & Individual & $\begin{array}{l}\text { Multiple } \\
\text { Individual }\end{array}$ & $\begin{array}{c}\text { Small } \\
\text { Business }\end{array}$ & $\begin{array}{c}\text { Large } \\
\text { Business }\end{array}$ & $\begin{array}{c}\text { Government } \\
(\mathrm{N})\end{array}$ & $\begin{array}{c}\text { Total \% } \\
(\underline{N})\end{array}$ \\
\hline & & (N) & $(\mathrm{N})$ & $(N)$ & & \\
\hline Individual & $\begin{array}{l}8.3 \\
(2)\end{array}$ & $\begin{array}{l}10 \\
(1)\end{array}$ & $\begin{array}{c}16.7 \\
(6)\end{array}$ & $\begin{array}{c}15.4 \\
(4)\end{array}$ & $\begin{array}{l}7.8 \\
(19)\end{array}$ & $\begin{array}{c}9.8 \\
(328)\end{array}$ \\
\hline $\begin{array}{l}\text { Multiple } \\
\text { Individual }\end{array}$ & $\begin{array}{c}0 \\
0 \\
(0)\end{array}$ & $\begin{array}{c}22.2 \\
(2)\end{array}$ & $\begin{array}{c}14.3 \\
(2)\end{array}$ & $\begin{array}{c}36.4 \\
(4)\end{array}$ & $\begin{array}{c}20.0 \\
(1)\end{array}$ & $\begin{array}{c}18 \\
(50)\end{array}$ \\
\hline Classes & - & - & $\begin{array}{c}100 \\
(1)\end{array}$ & $\begin{array}{c}100 \\
(1)\end{array}$ & $\begin{array}{l}100 \\
(1)\end{array}$ & $\begin{array}{c}0 \\
(3)\end{array}$ \\
\hline Small Business & $\begin{array}{c}14.3 \\
(1)\end{array}$ & $\begin{array}{c}33.4 \\
(1)\end{array}$ & $\begin{array}{l}40 \\
(4) \\
\end{array}$ & - & $\begin{array}{l}25 \\
(1) \\
\end{array}$ & $\begin{array}{c}25 \\
(28)\end{array}$ \\
\hline Large Business & $\begin{array}{c}42.9 \\
(3)\end{array}$ & $\begin{array}{c}66.7 \\
(2)\end{array}$ & $\begin{array}{c}66.7 \\
(2)\end{array}$ & - & - & $\begin{array}{l}53.8 \\
(13)\end{array}$ \\
\hline $\begin{array}{c}\text { Voluntary } \\
\text { Organization }\end{array}$ & - & - & - & - & $\begin{array}{c}50 \% \\
(1) \\
\end{array}$ & $\begin{array}{l}50 \\
(2) \\
\end{array}$ \\
\hline Government & $\begin{array}{c}50 \% \\
(3)\end{array}$ & $\begin{array}{c}66.7 \% \\
(2)\end{array}$ & - & - & $\begin{array}{c}100 \% \\
(1)\end{array}$ & $\begin{array}{c}60 \\
(10)\end{array}$ \\
\hline
\end{tabular}

For the tables used to generate the data in the tables above $N=434$, Chi-square $=44.92, d f=20, p<0.01$. 


\section{Net Advantage by Organizational Level}

Further considering litigant success, it is necessary to discuss the net advantage for each organizational class, as was generally outlined in the Variables section above. The net advantage is a better indicator of success than raw success rates, and according to Songer and Sheehan, the reasoning is simple: Net advantage considers court success independent of the relative frequency by which a litigant class appears in court as a respondent or appellant (1992:240-241). This is important when there is such a high tendency for affirmation, which can create a disproportionate success rate, especially if a class appears much more in court as a respondent, as is the case for government parties in this study. The measure is also particularly useful because the affirmation rate in the current study reached $85.7 \%$, exceeding the Songer and Sheehan study, which reported 84\%. The significance tests offered further support for this finding (For the tables from which this figure originates: Chi-squared 44.92, $d f=20, p<0.001$ ).

In Table $2 \mathrm{a}$ and Table $2 \mathrm{~b}$ is the net advantage of each organizational class, showing first the respondent success rate for each organizational level then subtracting from that all opponents' success rates when the class was a respondent. Generally stated, the data here reflect positive support for the theoretical proposition (H1): The difference between highest and lowest index of net advantage is $57.7 \%$ (by the expanded organizational measure) and $60.8 \%$ (by the Songertype) ${ }^{5}$ only slightly lower than the $63.3 \%$ reflected in the Songer and Sheehan study. This magnitude of difference in advantage between the highest and lowest organizational levels gives fairly consistent support for the theoretical prediction that greater court success rates will accompany higher organizational levels.

As said before, Songer and Sheehan (1992) suggest that a linear trend between success and organizational level is expected to support the theoretical framework, but the net advantage value

\footnotetext{
${ }^{5}$ These figures were based on tabulations whose chi-squared tests reflected a 0.001 significance or better.
} 
in this study's results actually becomes more negative for multiple individuals $(-10.6)$ than individuals (-6.6), conflicting with a linear trend. Though this detail deviates slightly from the linear expectation of Songer and Sheehan, the trend for net advantage here is still mostly linear in Table $2 \mathrm{~b}$ (Chi-squared $=36.74, d f=12, p<0.001$ ) and nearly perfectly linear in Table $2 \mathrm{a}$. The gravity of the aforementioned deviation (and the overall advantage values that show multiple individuals accordingly slightly higher, as well: $21.8 \%$ v. $20.4 \%$ in Table 2 b) must also be considered lightly. Fewer cases existed for multiple individuals than for individuals (50 as opposed to 328), and furthermore, the increased complexity of my expanded organizational classification strategy may point to another relationship between court favor and organizational level. Again, when the organizational categories for net advantage in this study are collapsed according to the Songer-style strategy (Table 2a), the trend still appears linear with strong significance (Chi-squared=31.64, $d f=4$, $p<0.001)$.

I emphasize here that in Table $2 \mathrm{~b}$ 'classes' realized a $0 \%$ success rate as both appellant and respondent, though this finding should be approached with caution because so few cases existed in which this organizational class appeared as a litigant $(N=3)$. Similarly, voluntary organizations won $50 \%$ of the time, but there were also too few cases to give this finding much credibility $(N=2)$. Aside from the aforementioned instances of too few cases for serious comparison, the success pattern in Table $2 \mathrm{~b}$ is generally linear as expected, supporting the proposition that law reacts more harshly against the less organized. Individuals succeeded exactly $9.8 \%$ of the time, while multiple individuals won $18 \%$ of cases; small business won $25 \%$ of the time, and large business had $53.8 \%$ success, while government again came out on top with $60 \%$ success. Significance testing lends better support to these findings (Chi-squared=36.74, $d f=12, p<0.01$ ) and further support to this study's test that law will better favor higher organizational levels (H1). 
Table 2a. Success Rates (\%) by Songer-Style Litigant: WV Supreme Court of Appeals

\begin{tabular}{|c|c|c|c|c|}
\hline Litigant & $\begin{array}{c}\text { Success } \\
\text { As } \\
\text { Appellant } \\
(N)\end{array}$ & $\begin{array}{c}\text { Opponent's } \\
\text { Success } \\
\text { When } \\
\text { Respondent } \\
(N)\end{array}$ & $\begin{array}{c}\text { Net } \\
\text { Advantage }\end{array}$ & $\begin{array}{c}\text { Combined Success Rate as } \\
\text { Appellant \& Respondent } \\
\%\end{array}$ \\
\hline Individual & $\begin{array}{c}10.8- \\
(381)\end{array}$ & $\begin{array}{c}20.5= \\
(83)\end{array}$ & -9.7 & 23.1 \\
\hline Business & $\begin{array}{c}35- \\
(43)\end{array}$ & $\begin{array}{c}23.4= \\
(94)\end{array}$ & 11.6 & 63.5 \\
\hline Government & $\begin{array}{c}60- \\
(10)\end{array}$ & $\begin{array}{c}8.9= \\
(257)\end{array}$ & 51.1 & 89.9 \\
\hline
\end{tabular}

For the tables used to generate the data in the tables above $N=434$, Chi-square $=31.64, d f=4, p<0.001$.

Table 2b. Success Rates (\%) by Songer-type Organization: WV Supreme Court of Appeals

\begin{tabular}{|c|c|c|c|c|}
\hline Litigant & $\begin{array}{l}\text { Success } \\
\text { As } \\
\text { Appellant } \\
(N)\end{array}$ & $\begin{array}{c}\text { When } \\
\text { Respondent, } \\
\text { Opponent's } \\
\text { Success Rate } \\
(N)\end{array}$ & $\begin{array}{c}\text { Net } \\
\text { Advantage }\end{array}$ & $\begin{array}{c}\text { Combined Success Rate as } \\
\text { Appellant \& Respondent } \\
\%\end{array}$ \\
\hline Individual & $\begin{array}{c}9.8- \\
(328)\end{array}$ & $\begin{array}{c}16.4 \\
(55)\end{array}=$ & -6.6 & 20.4 \\
\hline $\begin{array}{c}\text { Multiple } \\
\text { Individuals }\end{array}$ & $\begin{array}{l}18- \\
(50)\end{array}$ & $\begin{array}{c}28.6= \\
(28)\end{array}$ & -10.6 & 21.8 \\
\hline Classes & $\begin{array}{c}0 \\
(3)\end{array}$ & $\begin{array}{c}0 \\
(0)\end{array}$ & $\sim$ & 0 \\
\hline Small Business & $\begin{array}{l}25- \\
(28)\end{array}$ & $\begin{array}{c}26.9= \\
(52)\end{array}$ & -1.9 & 26.3 \\
\hline Large Business & $\begin{array}{c}53.8- \\
(13)\end{array}$ & $\begin{array}{l}19= \\
(42)\end{array}$ & 34.8 & 27.3 \\
\hline $\begin{array}{c}\text { Voluntary } \\
\text { Organization }\end{array}$ & $\begin{array}{c}50- \\
(2)\end{array}$ & $\begin{array}{c}0 \\
(0)\end{array}$ & $\sim$ & $50^{\sim}$ \\
\hline Government & $\begin{array}{l}60- \\
(10)\end{array}$ & $\begin{array}{l}8.9= \\
(257)\end{array}$ & 51.1 & 89.9 \\
\hline
\end{tabular}

For the tables used to generate the data in the tables above $N=434$, Chi-square $=36.74, d f=12, p<0.001$. 
As in former studies, evidence supports the theoretical stance that increased organization coincides with increased legal favorability through court success (Songer and Sheehan 1992; Wheeler et al. 1987). Though I achieved this rationale via a general array of cross-tabulations, the data somewhat consistently point to this, Individuals generally succeeded less than all other classes, and government was likewise the most successful of litigants. Furthermore, the index of net advantage in Table 2a shows that, independent of any influence by the high propensity for the appeals court to affirm, individuals still are substantially less successful than higher organizational classes. Businesses in turn are approximately twice as so advantaged. An even more significant result comes from Table $2 \mathrm{~b}$ : the fact that government is about eight times more favored in court, according to its net advantage of 51.1, than individuals, who scored a mere -6.6 (Chisquared $=36.74, d f=12, p<0.001$ ), The results here and in the Songer and Sheehan study offer support for Black's proposition regarding success and organizational strength and for this study's corresponding research hypothesis (H1).

In Table $3 \mathrm{a}$ and Table $3 \mathrm{~b}$, the net advantage measure appears again, listing the percentage difference by which more successful parties prevailed. The significance here is that unlike in Tables $1 \mathrm{a}, 1 \mathrm{~b}, 2 \mathrm{a}$, and $2 \mathrm{~b}$, the data in Tables $3 \mathrm{a}$ and $3 \mathrm{~b}$ only consider cases in which an organizational class appeared against other classes; the latter tables exclude cases in which classes appeared as opponents against the same organizational level. The overall purpose of generating the comparisons in Tables $3 \mathrm{a}$ and $3 \mathrm{~b}$ was to consider more intensively the party strength-success relationship, in following previous researchers (Songer and Sheehan 1992; Wheeler, Cartwright, Kagan, and Freeman 1987). According to the output, individuals sometimes actually succeeded against slightly higher levels of organization, particularly against multiple individuals and against business (by $10 \%$ and by $2.4 \%$, respectively — see Table $3 \mathrm{~b}$ ), while government again succeeded the most when appearing as litigants, both against individuals (by $47 \%$ and $42 \%$ net advantage) and against multiple individuals (Table 3b only). On the other hand, Table 3a shows the expected
Theo Malone 4/15/2015 2:04 PM

Formatted: Line spacing: double

Theo Malone 4/15/2015 2:05 PM

Deleted: notion with consistency

Theo Malone 4/15/2015 2:05 PM

Deleted: in lower rates

\section{Theo Malone 4/15/2015 2:06 PM}

Deleted: so

Theo Malone 4/15/2015 2:06 PM

Deleted: by this measure

Deleted: 11.2 
relationships with business and government succeeding consistently over individuals (by $14.2 \%$ and $47.6 \%$, respectively), except in one notable case when government did not come out ahead against business; business succeeded over government by a 33.3\% higher net advantage, although government never actually took on businesses as respondents in this comparison. Despite this latter unexpected deviation, all findings in Tables 3a hold substantial significance testing results (Chi-squared $=31.64, d f=4, p<0.001$ ). In Table $3 \mathrm{~b}$ results also carry considerable significance from such results (Chi-squared $=36.74, d f=12, p<0.001$ ). The important finding here is that again there is support that the higher the litigant's organizational level the more he or she will experience legal success (H1).

In Table $3 \mathrm{~b}$ classes showed a net advantage exceeding some other parties (by $100 \%$ versus small business, large business, and government), and voluntary organizations also enjoyed a better net advantage over government (42.7\%). It is important to note that these 'successes' did not include observations by which the 'losing' organizational levels had any comparable net advantage (e.g. there were no cases to compare in the matchups so the 'loser' net advantages were already ' 0 '). It is safe to assume that these numbers would be different in cases whereby comparisons could be made against more than just empty values for net advantage for these parties. These last findings at best should be approached with caution.

Table 3a. Net Advantage for Different Combinations of Parties (Songer-type)

\begin{tabular}{lll}
\multicolumn{2}{l}{ Combination of Parties } & Net Advantage \\
Individual & v. business & Business by $14.2 \%$ \\
Individual & v. government & Government by $47.6 \%$ \\
Business & v. government & $\sim \sim$ Business by $33.3 \%$ \\
\hline
\end{tabular}

For the tables used to generate the data in the tables above $N=434$, Chi-square $=31.64, d f=4, p<0.001$. 


\section{Table 3b. Net Advantage for Different Combinations of Parties (Expanded-type)}

Combination of Parties
$\begin{array}{ll}\text { Individual } & \text { v. multiple individual } \\ \text { Individual } & \text { v. small business } \\ \text { Individual } & \text { v. large business } \\ \text { Individuals } & \text { v. government }\end{array}$

Multiple Individuals v. small business

Multiple Individuals. v. large business

Multiple Individuals. v. government
Net Advantage

Individuals by $10 \%$

Individuals by $2.4 \%$

Lg. Business by $27.5 \%$

Government by $42.2 \%$

Sm. Business by $19.1 \%$

Lg. Business by $30.3 \%$

Government by $46.7 \%$

Classes by $100 \% \sim ~$

Classes by $100 \%$

Classes by $100 \% \sim ~$

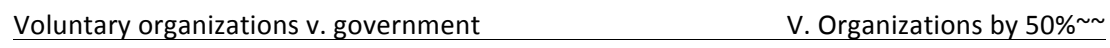

For the tables used to generate the data in the tables above $N=434$, Chi-square $=36.74, d f=12, p<0.001$.

$\sim \sim$ Comparison made in cases of zero observations for one of the listed parties

In keeping with Songer and Sheehan (1992) and Wheeler et al (1987) the data in Tables 3a and 3b exclude cases where parties faced those of the same organizational level.

Another tabular comparison in Tables $4 \mathrm{a}$ and $4 \mathrm{~b}$ shows the index of relative strength for litigants who were opponents of different organizational levels; Songer and Sheehan also utilized this comparison and again predicted a positive linear output for success and organizational strength
Theo Malone 4/15/2015 2:11 PM

Deleted: appears

Theo Malone 4/15/2015 2:11 PM

Deleted:ing 
(1992:246). Likewise, I use this measure to garner support for the research hypothesis (H2) that the higher the difference of relative strength between litigants, the higher will be the appellant success rates, Relative strength equals appellant minus respondent; this assumes one first assigns each litigant to an organizational number on the scale of 1 to 3 for Songer-type organizational classification and 1 to 7 for the expanded-type of organization. Iobtained the indices finding the difference of litigant organizational level in all cases that were wins (not 'affirmed') and reported these with the winning percentages for each litigant class matchup. This measure in Table $4 \mathrm{a}$ and $4 \mathrm{~b}$ shows appellant success rates in terms of the relative organizational superiority (or inferiority).

The organizational strength variable shows the percentage tendency of winning for appellants with the highest orders of organization (such as government, which was coded as '7' or ' 3 ') compared with every other organizational level. Conversely, it shows the winning tendencies for lower organizational levels (such as individuals, coded ' 1 ') against other classes, and it shows every comparison of in-between matchups (such as for business against other levels and classes and so on). This is important because the success percentages can be seen as a distribution of court success by comparing each organizational class to every possible opponent,

As already stated above and as mentioned by Songer and Sheehan $\_$if a linear presentation of increased rate of court success corresponds to an increasing relative strength index, the general supposition is that the theoretical framework is supported. The highest and lowest index differences in Tables $4 \mathrm{a}$ and $4 \mathrm{~b}$ below correspond to the highest and lowest success rates (government v. individual and individual v. government, respectively), and all relative strength differences in Table 4a follow a linear pattern with success, and that with considerable significance (Chi-square $=87.68, d f=8, p<0.001$ ). On the other hand, the intermediate relative strength differences in Table $4 \mathrm{~b}$ do not occur in a completely linear fashion, thus creating an overall non-
Theo Malone 4/15/2015 2:11 PM

Deleted: derive

Theo Malone 4/15/2015 2:11 PM

Deleted: for

Theo Malone 4/15/2015 2:11 PM

Deleted: for appellants

Theo Malone 4/15/2015 2:11 PM

Deleted: then

Theo Malone 4/15/2015 2:12 PM

Deleted: the

Theo Malone 4/15/2015 2:13 PM

Deleted: (respondent)

Theo Malone 4/15/2015 2:16 PM

Deleted: In the output, support is expected to coincide with a

Theo Malone 4/15/2015 2:14 PM

Deleted: presentation

Theo Malone 4/15/2015 2:15 PM

Deleted: increased

Theo Malone 4/15/2015 2:14 PM

Deleted: levels of

Theo Malone 4/15/2015 2:14 PM

Deleted: that

Theo Malone 4/15/2015 2:15 PM

Deleted: (positive) index of

Theo Malone 4/15/2015 2:17 PM

Deleted: differences

Theo Malone 4/15/2015 2:17 PM

Deleted: combined with

Theo Malone 4/15/2015 2:18 PM

Deleted: results 
linear result. As discussed earlier, this difference may result from something a more complex organizational classification reveals and does not mean the tests do not offer theoretical support.

In summary, Table $4 \mathrm{a}$ and Table $4 \mathrm{~b}$ show the least levels of success for individuals against government (relative strength indices are -2 in Table $4 \mathrm{a}$ and -6 in Table $4 \mathrm{~b})$ : at $8 \%(N=250)$ and $7.8 \%(N=244)$, respectively. For the opposite extreme, government versus individuals actually showed $50 \%$ to $55.6 \%$ success rates (considering both tables). Though these terminal ends of the comparisons occur as expected, the intermediate values do not follow the same trend with increasing success levels. The exception is in cases of ' 0 ' index relative strength: In both tables, the levels of success matched with this value are somewhat lower (in Table $4 \mathrm{~b}$ at $16.7 \%$ ) and somewhat higher (Table $4 \mathrm{~b}$ at $20.5 \%$ ) than a linear expectation would predict. Thus, when considering Table 4b, one can see the results are non-linear for the expanded organizational classification Particularly, only $7.8 \%$ success accompanies the relative strength index of -6 (individual v. government), and the intermediate range of indices -3 to -5 follow with $22.5 \%$ success, while an index of -1 coincides with $12.5 \%$ success. For relative strength indices of 0 difference in litigant organizational levels, the percentage jumps to $20.5 \%$, while +1 to +2 coincides with $17.6 \%$, and the range of +3 to +5 comes at second place, at $40 \%$ success, just below the rate for +6 (government v. individual) which scored $50 \%$ success. These findings are quite significant, $(N=434$, Chi-square $=192.75, d f=6, p<0.001)$, and though this distribution does not conform to that of prior researchers' linear expectations, its difference is important, as it may justify further exploration through more intensive study due to the more complex organizational classification.

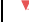

Table 4a. Appellant Success by Relative Strength Index (Songer-type Organization)

Index of Relative Strength

(Appellant - Respondent)
Appellant Wins

$\%$
$(N)$
Theo Malone 4/15/2015 2:24 PN

Deleted: more inconsistent

Theo Malone 4/15/2015 2:25 PM

Deleted: linear as well-defi 
For the table used to generate the data frequencies in the table above $N=434$, Chi-square $=87.68, d f=8, p<0.001$.

Table 4b. Appellant Success by Relative Strength Index (Expanded-type Organization)

\begin{tabular}{llc} 
Index of Relative Strength & Appellant Wins & $(N)$ \\
(Appellant - Respondent) & & 244 \\
\hline-6 & $7.8 \%$ & 71 \\
-5 to -3 & $22.5 \%$ & 32 \\
-2 to -1 & $12.5 \%$ & 44 \\
0 & $20.5 \%$ & 17 \\
+1 to +2 & $17.6 \%$ & 20 \\
+3 to +5 & $40 \%$ & 6 \\
\hline+6 & $50 \%$ & \\
\hline
\end{tabular}

For the table used to generate the data frequencies in the table above $N=434$, Chi-square=192.75, $d f=6, p<0.001$.

\section{Advantage of Civil over Criminal Cases}

A final comparison in Table 5 offers some support for Black's theoretical prediction that civil cases will prevail in terms of appellant successes over criminal ones (H3). Table 5 contains a modified display of win rates for organizational classes, calculated by removing from it all criminal 
cases so that only civil (TCR) style cases remain. The results show a favorable success rate for most classes engaged in civil proceedings; the case type division was not too distant from an even split, with $47 \%$ civil cases and $53 \%$ criminal ones. For civil cases, $22.2 \%$ were wins $(N=203$, Chisquared $=38.88, d f=24, p=0.03$ ), while the remaining criminal cases reflected only a $7.4 \%$ success rate, reflecting substantial significance $(N=231$, Chi-squared $=184.24, d f=24, p<0.001)$, thus garnering support for Black's theoretical framework and the research hypothesis (H3) that civil appeals will realize greater success than criminal ones.

Table 5a. Win Rate (\%) for Appellants in Civil Proceedings vs. Other Classes of Opponents

\begin{tabular}{|c|c|c|c|c|c|c|}
\hline Respondent $\rightarrow$ & $\frac{\text { Individual }}{(N)}$ & $\frac{\text { Multiple }}{\frac{\text { Individual }}{(N)}}$ & $\frac{\frac{\text { Small }}{\text { Business }}}{(N)}$ & $\frac{\frac{\text { Large }}{\text { Business }}}{(N)}$ & $\frac{\text { Government }}{(N)}$ & $\frac{\text { Total }}{(N)}$ \\
\hline Individual & $\frac{9.1}{(22)}$ & $\frac{10}{(10)}$ & $\frac{26.1}{(23)}$ & $\frac{15.4}{(26)}$ & $\frac{15.8}{(19)}$ & $\frac{16}{(100)}$ \\
\hline $\begin{array}{l}\text { Multiple } \\
\text { Individual }\end{array}$ & $\frac{0}{(11)}$ & $\frac{22.2}{(9)}$ & $\frac{14.3}{(14)}$ & $\frac{36.4}{(11)}$ & $\frac{20}{(5)}$ & $\frac{18}{(50)}$ \\
\hline Classes & $=$ & $=$ & $\frac{0}{(1)}$ & $\frac{0}{(1)}$ & $\frac{0}{(1)}$ & $\frac{0}{(3)}$ \\
\hline $\begin{array}{l}\text { Small } \\
\text { Business }\end{array}$ & $\frac{14.3}{(7)}$ & $\frac{33.3}{(3)}$ & $\frac{40}{(10)}$ & $\frac{0}{(4)}$ & $\frac{25}{(4)}$ & $\frac{25 \%}{(28)}$ \\
\hline $\begin{array}{c}\text { Large } \\
\text { Business } \\
\end{array}$ & $\frac{42.9}{(7)}$ & $\frac{66.7}{(3)}$ & $\frac{66.7}{(3)}$ & $\begin{array}{c}- \\
(0) \\
\end{array}$ & $\begin{array}{c}- \\
(0) \\
\end{array}$ & $\begin{array}{l}53.8 \\
(13) \\
\end{array}$ \\
\hline $\begin{array}{c}\text { Voluntary } \\
\text { Organization }\end{array}$ & $=$ & $=$ & $=$ & $=$ & $\frac{50}{(2)}$ & $\frac{50}{(2)}$ \\
\hline Government & $\frac{66.7}{(3)}$ & $\frac{66.7}{(3)}$ & $\begin{array}{c}- \\
\overline{-} \\
(0) \\
\end{array}$ & $\begin{array}{c}- \\
(0) \\
\end{array}$ & $\begin{array}{r}100 \\
(1) \\
\end{array}$ & $\frac{71.4}{(7)}$ \\
\hline
\end{tabular}

For the tables used to generate the data in the tables above $N=203$, Chi-square $=38.88, d f=24, p<0.05$.

1. 


\section{Limitations and Future Research}

Perhaps the single greatest limitation in the current study is that it only includes for analysis cases from a two-year period from West Virginia Supreme Court of Appeals. Additionally, and as a result of time constraints, the study includes only criminal and civil actions, which necessarily excludes a large volume of appeals cases ruled upon during the same time period. Though somewhat useful for comparing varying degrees of litigant organizational level (as these levels generally only vary in civil proceedings), this case selection choice involves a limitation of case styles based on a lack of serious time and resources with which to sample and analyze a large frame of data Since I determined it was best to narrow this study's chronological frame to the given West Virginia courts data due to time limits, a future study may widen the case type and the time frame covered in order to address this deficiency, It would be advantageous and prudent to select from multiple state courts and perhaps several federal supreme courts venues, from higher tribunals such as international organizations to which governments are subordinate or accountable, and from wider time frames. This would allow for a longitudinal analysis and a more representative data set, as well as cases involving litigants having higher levels of organization, One such way of doing this may be in formulating a content analysis of legal decisions involving international law and large corporate entities over time (as in recent cases such as energy conglomerate Vattenfall's 2012 civilactions that won an excess of 10 million Euros against the German government for statutory restrictions of the former's nuclear power plant operations). Additionally, future studies could further explore the compared win rates of civil versus criminal cases, consider a business advantage question, and perhaps test ąresearch question regarding social distance (morphology) of litigants versus court success, assuming that such detail could be gathered from other data sets.
Theo Malone 4/15/2015 2:28 PM

Deleted: re

Theo Malone 4/15/2015 2:29 PM

Deleted: Also of limit to this study's relevant significance is the time frame of the sample; only a 2-year period is selected for sampling

Theo Malone 4/15/2015 2:30 PM

Deleted: The decisive

Theo Malone 4/15/2015 2:31 PM

Deleted: ing of

Theo Malone 4/15/2015 2:29 PM

Deleted: those cases chosen from Theo Malone 4/15/2015 2:31 PM

Deleted: set was the best choice for the research, given the available time

investment with which to conduct the research. A

Theo Malone 4/15/2015 2:32 PM

Deleted: , as well

Theo Malone 4/15/2015 2:32 PM

Deleted: $\mathrm{n}$ other words, i

Theo Malone 4/15/2015 2:32 PM

Deleted: ing

Theo Malone 4/15/2015 2:32 PM

Deleted: very

Theo Malone 4/15/2015 2:33 PM

Deleted: such

Theo Malone 4/15/2015 2:33 PM

Deleted: as the

Theo Malone 4/15/2015 2:33 PM

Deleted: giant

Theo Malone 4/15/2015 2:33 PM

Deleted: legal

Theo Malone 4/15/2015 2:34 PM

Deleted: latter's

Theo Malone 4/15/2015 2:34 PM

Deleted: the former's

Theo Malone 4/15/2015 2:34 PM

Deleted: on German soil

Theo Malone 4/15/2015 2:35 PM

Deleted: more detailed and measured Theo Malone 4/15/2015 2:34 PM

Deleted: as

Theo Malone 4/15/2015 2:35 PM

Deleted: regards 


\section{Conclusion}

In pursuit of empirical tests of both Black's theoretical propositions and of Galanter's predictions about organization and the resultant conditions of the law, this research did obtain some support

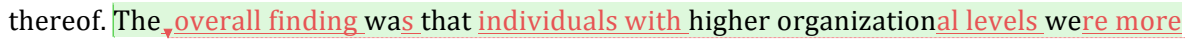
successful in West Virginia appeals, and those of the lower organizational classes were less successful. Aside from obvious differences in data selection, I set out to replicate as much as possible the approach of Songer and Sheehan in their 1992 study. I discovered that an expanded and more complex organizational level classification scheme (such as was used here) may reveal a different than expected pattern in data findings regarding court success and litigant strength.

Though the study results here did not follow a completely linear pattern of variation, clearly the highest order of success was paired with the highest order of organization: government.

Conversely, the least organized party, individuals, corresponded with the lowest level of success by the relative strength measure and in general results; these findings generally supported the theoretical framework. It was the strength indexes in the in-between bounds of the range of organizational level that demarcated from a linear progression; that these values digressed may hold some worth for future investigations with more complex designations of litigant organization.

Additionally, my research compared the success rates for civil versus criminal cases and also garnered support for the theoretical framework of Donald Black. Accordingly, I had correctly assumed that civil cases would have lower affirmation rates (higher success) due to the implied greater differences in organizational statuses of litigants in criminal cases. Civil cases showed significantly higher levels of success, than criminal ones (22\% v. 7.8\%; $p<0.05)$. Though the breadth of the research frame in this study was limited, its outcome lays some groundwork for a more thorough project. More details about organization and examination of a research question based on race or socioeconomic status could also allow for a widened frame of theoretical questioning. While
Theo Malone 4/15/2015 2:35 PM

Deleted: setting out in

Theo Malone 4/15/2015 2:35 PM

Deleted: of

Theo Malone 4/15/2015 2:36 PM

Deleted: the

Theo Malone 4/15/2015 2:35 PM

Deleted: coincident

Theo Malone 4/12/2015 5:42 PM

Deleted: notion

Theo Malone 4/14/2015 12:56 PM

Deleted: conveys success

Jason Phillip Manning 5/1/2015 12:12 PM

Comment [13]: You didn't find a "notion." You would that organizations are more successful.

Also, what I just typed sounds much better than "organization conveys success was an overall finding." You must get over your love affair with the passive voice.

Theo Malone 4/12/2015 5:42 PM

Deleted: was an overall finding.

Theo Malone 4/14/2015 12:58 PM

Deleted: a

Theo Malone 4/15/2015 2:36 PM

Deleted: here

Theo Malone 4/15/2015 2:37 PM

Deleted: general

Theo Malone 4/15/2015 2:37 PM

Deleted: with the

Theo Malone 4/15/2015 2:38 PM

Deleted: distance of

Theo Malone 4/15/2015 2:38 PM

Deleted: .

Theo Malone 4/15/2015 2:39 PM

Deleted: for the 
a socioeconomic question may be appropriate in a West Virginia-based study, to consider factors of race may prove more fruitful in another state, perhaps in the southeastern United States or in urban areas reflecting more diverse demographic features.

Generally stated, one should bring clout to the courtroom in West Virginia's Appellate Courts, whether by means of organizational status, superior legal representation, or amici influence or some combination thereof. It is clout that is largely thought to represent organizational advantage in West Virginia and elsewhere.

Jean-Jacques Rousseau said that inequality is harmless to the social order in general, so long as this difference and disparity is not too noticeable. It is after inequality grows beyond subtle notice that problems will begin and persist (Rousseau 2010[1913]). Ultimately one may argue that City Hall perpetuates inequality in serving itself, and that one can't fight City Hall and win in most cases because its inherent organizational advantage (and perhaps other factors not investigated here) will undoubtedly assure its victory.

I do not intend to imply that one can't fight City Hall or the established order through law, or that one should not try. On the contrary, it is exactly because of the unleveled legal playing field that one needs to pursue fair treatment of the law. The intent of this study is to show that the relationship of status and legal favor is a complex one, and it warrants both future research and likely subsequent reforms. Findings in future studies may further determine that the key determinant of court success is organization in its varying degrees and that the best contenders before the law are those of the highest organizational status when race and other factors come into play. Ultimately it is the expectation here that circumstances will continue to favor the haves, the upper-dogs, and the privileged membership of City Hall, and change must occur in the name of legal egalitarianism.

Theo Malone 4/15/2015 2:39 PM

Deleted: could prove

Theo Malone 4/15/2015 2:39 PM

Deleted: ,

Theo Malone 4/15/2015 2:43 PM

Deleted: S

Theo Malone 4/15/2015 2:43 PM

Deleted: simply

Theo Malone 4/14/2015 1:24 PM

Deleted: plan to

Theo Malone 4/15/2015 2:43 PM

Deleted: cases 


\section{Reference}

Black, Donald. 1976. The Behavior of Law. New York, NY: The Academic Press.

Black, Donald. 1989. Sociological Justice. New York, NY: Oxford University Press.

Black, Donald. 2010. "How Law Behaves: An Interview With Donald Black." International Journal of Law, Crime, and Justice (38):37-47.

\section{Duke, Allan. 2011. "Plea Deal Ends Willie Nelson Pot Prosecution." CNN.com \\ Retrieved 11 April 2015.}

(http://edition.cnn.com/2011/SHOWBIZ/celebrity.news.gossip/06/07/willie.nelson.fine/)

Galanter, Marc. 1974."Why the 'Haves' Come Out Ahead: Speculations on the Limits of Legal Change." Law \& Society Review 9(1): 95-160.

Liptak, Adam. 2008. "Motion Ties W. Virginia Justice to Coal Executive." New York Times: January $15,2008$.

\section{Retrieved 11 April 2015.}

\section{(http://www.nytimes.com/2008/01/15/us/15court.html)}

Marshall, Edward. 2014. "Lawsuit Against City: Police in Wayne Jones Shooting Dismissed.” Retrieved 2 December 2014. (http://journal-news.net/page/content.detail/id/620107/Lawsuitagainst-city--police-in-Wayne-Jones-shooting-dismissed.html?nav=5281)

Marx, Karl and Engels, Frederick. 1955 [1848]. The Communist Manifesto. New York, NY: Appleton Century Crofts.

Mills, C.W. 1956. The Power Elite. New York, NY: Oxford University Press.

Reiman, Jeffrey. 1995. The Rich Get Richer and the Poor Get Prison: Ideology, Crime, and Criminal Justice. Needham Heights, MA: Allyn and Bacon.

Rousseau, Jean-Jacques. 2010 [1913]. The Social Contract \& Discourses. New York: E.P.Dutton \& Co.; Bartleby.com. Retrieved 4 April 2014. (www.bartleby.com/168/).

Savage, S.P. 2002. “The Geometry of Law: An Interview with Donald Black.” International Journal of the Sociology of Law 30 (99):

Songer, Donald R. and Reginald S. Sheehan. 1992. "Who Wins Appeals? Upperdogs and Underdogs in the United States Courts of Appeals. American Journal of Political Science 36(1):235-258.

Songer, Donald R., Reginald S. Sheehan, and Susan Brodie Haire. 1999 “Do the 'Haves' Come Out Ahead Over Time? Applying Galanter's Framework to Decisions of the US Courts of Appeals, 19251988." Law \& Society Review 33 (4):811-832.

Urbina, Ian. 2008. "University Investigates Whether Governor's Daughter Earned Degree." New York Times: January 22, 2008. 
Retrieved 13 April 2015.

(http://www.nytimes.com/2008/01/22/us/22heather.html?pagewanted=1\&n=Top/Reference/Ti mes\%20Topics/Subjects/G/Governors\%20(US)\&_r=0)

US Department of Justice. Federal Bureau of Investigation. 2014. "FBI Releases Expanded Crime Statistics for 2013." December 2014. Washington, D.C.: Criminal Justice Information Services Division.

US Department of Justice Civil Rights Division. 2015. "Investigation of The Ferguson Police." Department. Retrieved 4 April 2015. (http://www.justice.gov/sites/default/files/opa/pressreleases/attachments/2015/03/04/ferguson_police_department_report.pdf )

Retrieved 11 April 2015

(http://www.fbi.gov/news/stories/2014/december/fbi-releases-2013-national-incident-basedreporting-system-statistics/fbi-releases-2013-national-incident-based-reporting-system-statistics)

Wanner, Craig. 1974. The Public Ordering Of Private Relations: Part Two: Winning In Litigation." Law and Society Review 9(2):293-306.

Washington Post. 2014. "Asset Seizures Fuel Police Spending." Washington Post: October 11, 2014.

Retrieved 11 April 2015.

(http://www.washingtonpost.com/sf/investigative/2014/10/11/cash-seizures-fuel-policespending/)

West Virginia University. 2008. "Report of Investigative Review Panel for Review of Executive MBA Program Records." West Virginia University Faculty Senate: April 21, 2008.

Also available at: (http://docs.facultysenate.wvu.edu/panel_report_4-23-08.pdf)

Wheeler, Stanton, Bliss Cartwright, Robert Kagan and Lawrence Friedman. 1987. “Do the 'Haves' Come Out Ahead? Winning and Losing in State Supreme Courts, 1870-1970." Law and Society Review 21:403-405. 